\title{
Analogs of GnRH-I and GnRH-II inhibit epidermal growth factor-induced signal transduction and resensitize resistant human breast cancer cells to $\mathbf{4 0 H}$-tamoxifen
}

\author{
Andreas R Günthert, Carsten Gründker, Agnes Olota, Julia Läsche, Nicola Eicke and Günter Emons \\ Department of Gynecology and Obstetrics, Georg-August-University, Robert-Koch-Street 40, D-37075 Göttingen, Germany
}

(Correspondence should be addressed to G Emons; Email: emons@med.uni-goettingen.de)

\begin{abstract}
About $50-64 \%$ of human breast cancers express receptors for GnRH-I. Direct antiproliferative effects of analogs of GnRH-I on human breast cancer cell lines have been shown. They are at least in part mediated by antagonizing growth promoting effects of estradiol, epidermal growth factor (EGF) or insulin-like growth factor. Recently, expression of a putative receptor for GnRH-II in human tissues was demonstrated. Antiproliferative effects of GnRH-II in human endometrial and ovarian cancer cells were shown not to be mediated through the GnRH-I receptor. Now we demonstrate direct antiproliferative effects of the GnRH-I analog Triptorelin and the GnRH-II analog [D-Lys ${ }^{6}$ GnRH-II in MCF-7 and T47D human breast cancer cells expressing GnRH-I receptors and putative GnRH-II receptors. Pretreatment with Triptorelin or [D-Lys $\left.{ }^{6}\right] \mathrm{GnRH}-\mathrm{II}$ blocked EGF-induced autophosphorylation of EGF receptor and activation of mitogen-activated protein kinase (extracellular-signal-regulated kinase 1/2 (ERK1/2)) in these cells. In sublines of MCF-7 and T47D cells, which were developed to be resistant to $40 \mathrm{OH}$-tamoxifen, HER-2/p185 was overexpressed. Pretreatment of these cell lines with Triptorelin or $\left[\mathrm{D}^{-\mathrm{Lys}^{6}}{ }^{6} \mathrm{GnRH}-\mathrm{II}\right.$ completely abolished resistance to $4 \mathrm{OH}$-tamoxifen, assessed by $4 \mathrm{OH}-$ tamoxifen-induced apoptosis. Analogs of GnRH-I and GnRH-II counteract EGF-dependent signal transduction in human breast cancer cells with expression of receptors for GnRH-I and GnRH-II. Through this mechanism, they probably reverse acquired resistance to 40H-tamoxifen mediated through overexpression or activation of receptors of the c-erbB family.
\end{abstract}

European Journal of Endocrinology 153 613-625

\section{Introduction}

About 50-64\% of human breast cancers express receptors for gonadotropin-releasing hormone I (GnRH-I), also called luteinizing hormone-releasing hormone (LHRH) (1-4). Direct antiproliferative effects of GnRH-I analogs have been described in GnRH-I receptor (GnRH-I-R)-positive breast cancer cell lines in vitro $(5-8)$. Various studies demonstrated that direct inhibitory effects of GnRH-I analogs in human breast cancer cells are mediated at least in part by an antagonism of growth-promoting factors, such as estradiol, epidermal growth factor (EGF) or insulin-like growth factor (IGF) (9-11). In addition, Szepeshazy et al. (12) demonstrated direct GnRH-I-mediated growth inhibition and significant decrease of expression of receptors for EGF and IGF-I in estrogen-independent MXT mouse mammary carcinoma inoculated in BDF1 mice, which had undergone bilateral surgical ovariectomy. GnRH-I inhibits the expression of $60 \mathrm{~S}$ acidic ribosomal phosphoproteins P1 and P2 in MCF-7 cells, and thus affects the rate of protein translation as one mechanism of direct antiproliferative effect of GnRH-I in human breast cancer cells (13). Previously we showed that GnRH-I analogs significantly reduced EGF-induced expression of the immediate early response gene c-fos in MCF-7 cells (14).

The expression of GnRH-I and its receptor, GnRH-I-R, as a part of a negative autocrine regulatory system and direct antiproliferative effects of GnRH-I analogs have been demonstrated in a number of human malignant tumors, including ovarian, endometrial and prostate cancers. These studies also indicated that the dichotomy of $\mathrm{GnRH}$ antagonists and agonists might not apply to the GnRH system in cancer cells (reviewed in (15)). The GnRH-I-R-mediated signal transduction in human ovarian and endometrial cancers couples to G-protein $\alpha_{\mathrm{i}}$ and activates a phosphotyrosine phosphatase counteracting EGF-induced tyrosine phosphorylation of EGF receptor (EGF-R), resulting in down-regulation of 
mitogen-activated protein kinase (MAPK; extracellularsignalregulated kinase 1/2 (ERK1/2)), down-regulated c-fos expression and inhibition of estrogen-responsive elements and cell proliferation (15-18). In addition, GnRH-I activates nucleus factor $\mathrm{\kappa B}(\mathrm{NF}-\kappa \mathrm{B})$ in ovarian cancer cells and protects these cells from doxorubicininduced apoptosis (19). GnRH-I induces activator protein 1 (AP-1) and JunD DNA binding and reduces proliferation by cell-cycle arrest in $\mathrm{G}_{0 / 1}$ phase in human ovarian and endometrial cancer cells (20). It is reasonable to speculate that comparable $\mathrm{GnRH}$-induced mechanisms of action exist in human breast cancer cells. In non-mammalian vertebrates three structural variants of GnRH were described in individual species, all decapeptides with almost similar amino acid composition but different functions in the regulation of reproduction. One of these GnRH variants is GnRH-II (also called chicken GnRH-II), which was totally conserved in structure in evolution from fish to mammals $(21-23)$. The existence of three forms of GnRH suggests that three cognate receptor types would also be present in vertebrates $(21,23)$. Recently we showed that GnRH-II has antiproliferative effects on human endometrial and ovarian cancer cells, in which mRNA for a putative GnRH-II-R was detected (24). The effects of GnRH-II were greater than those of the superactive GnRH-I agonist Triptorelin. Although attempts to sequence the GnRH-II-R in human tissues have failed until now, we demonstrated that growth-inhibitory effects of GnRH-II are not mediated through the GnRH-I-R (25). It might be speculated that in addition to the autocrine growth regulatory system based on the expression of GnRH-I a similar system exists involving the putative GnRH-II-R.

The development of acquired resistance to antiestrogens in breast cancer is a major therapeutic problem. In human breast cancer, lack of response to endocrine therapy is often associated with decreased expression of the estrogen receptor $\alpha(E R \alpha)$ and increased expression of the members of the c-erbB receptor family, including EGF receptor (EGF-R) and/or HER-2 oncogene product p185. HER-2/p185 overexpression results in hyperactivity of MAPK and tamoxifen resistance in MCF-7 cells (26). Inhibition of EGF-R/HER-2 kinase by specific inhibitor AG1478 reduced MAPK activity and enhanced tamoxifen action in resistant MCF-7 xenografts in athymic mice (26). In addition, treatment of MCF-7 cells resistant to tamoxifen with the inhibitor of EGF-R phosphotyrosine kinase (PTK), Iressa (ZD1839/gefitinib), or a monoclonal antibody to $\mathrm{p} 185$, trastuzumab (Herceptin ${ }^{\circledR}$ ), reduced MAPK (ERK1/2) activity and inhibited cell growth (27).

The aim of this study was to show direct antiproliferative effects of the GnRH-I analog [D-Trp $\left.{ }^{6}\right] \mathrm{GnRH}$ (Triptorelin) and the GnRH-II analog [D-Lys $\left.{ }^{6}\right] \mathrm{GnRH}-\mathrm{II}$ in human breast cancer cell lines MCF-7 and T47D. Then we demonstrated inhibitory effects of Triptorelin and [D-Lys $\left.{ }^{6}\right] \mathrm{GnRH}-\mathrm{II}$ on EGF-induced autophosphorylation of EGF-R and on MAPK (ERK1/2) activity. We developed sublines of MCF-7 and T47D cells with secondary resistance to antiproliferative effects of 40H-tamoxifen. These sublines were characterized and compared with parental cells for their expression of receptors for ER $\alpha$ and ER $\beta$, for expression of HER-2 oncogene product p185 and of EGF-R, and for expression for GnRH-I-R and GnRH-II-R. Finally, effects of Triptorelin, [D-Lys $\left.{ }^{6}\right] \mathrm{GnRH}-\mathrm{II}$ and Iressa on apoptosis induced by $4 \mathrm{OH}$-tamoxifen in parental cells and $4 \mathrm{OH}-$ tamoxifen-resistant sublines were analysed.

\section{Material and methods \\ Cell lines and culture conditions}

The human breast cancer cell lines MCF-7 and T47D were purchased from the American Type Culture Collection (ATCC, Manassas, VA, USA). MCF-7 and T47D cells were cultured at $37^{\circ} \mathrm{C}$ in a humidified atmosphere of $5 \% \mathrm{CO}_{2}$. The medium used was based on Earle's salts and contained 2-fold concentrations of Earle's minimal essential medium, vitamins, essential and nonessential amino acids (Biochrom, Berlin, Germany). Other components were $2.2 \mathrm{~g} / \mathrm{l} \mathrm{NaHCO}_{3}$ (Biochrom), $2.5 \mathrm{mg} / \mathrm{l}$ transferrin (Sigma, Deisenhofen, Germany) and $67 \mathrm{mg} / \mathrm{l}$ gentamycin sulfate (Biochrom). The medium was supplemented with 40 i.u./l insulin (Aventis, Frankfurt, Germany) and 10\% fetal calf serum (FCS; Roche, Mannheim, Germany). $24 \mathrm{~h}$ prior to each experiment cell monolayers were washed with PBS and medium was replaced by Phenol Red- and FCS-free medium.

\section{Establishment of MCF-7-TR and T47D-TR}

To develop sublines resistant to 4OH-tamoxifen, MCF-7 and T47D cells were kept in culture as described above plus $40 \mathrm{OH}$-tamoxifen (Sigma) at $125 \mathrm{nM}$. After 6 months of continuous exposure to $4 \mathrm{OH}$-tamoxifen these cells showed proliferation in medium containing 4OH-tamoxifen comparable to that of parental cells without 4OH-tamoxifen, indicating the development of cell lines resistant to the growth-inhibitory properties of $4 \mathrm{OH}$-tamoxifen. The resistant cell lines were named MCF-7-TR and T47D-TR, and were cultured for a further 3 months in medium containing $4 \mathrm{OH}$-tamoxifen before characterization studies.

\section{[ $^{3}$ H]Thymidine incorporation}

Prior to $\left[{ }^{3} \mathrm{H}\right]$ thymidine-incorporation assays we performed proliferation assays with increasing concentrations of Triptorelin and [D-Lys $\left.{ }^{6}\right] \mathrm{GnRH}-\mathrm{II}$ $(1 \mathrm{nM}-1 \mu \mathrm{M})$, which showed dose-dependent inhibition of proliferation in MCF-7 and T47D cells. After $72 \mathrm{~h}$ Triptorelin and [D-Lys ${ }^{6}$ G GnRH-II showed comparable growth-inhibitory effects on MCF-7 and 
T47D human breast cancer cells ( $1 \mathrm{nM}$, less than $10 \%$ growth inhibition; $100 \mathrm{nM}$, about $50 \%$ growth inhibition; $1 \mu \mathrm{M}$, about $80 \%$ growth inhibition). We focused further experiments on the dose of $100 \mathrm{nM}$ of each analog. $10^{7}$ cells were plated in 96-well dishes (Nunc, Roskilde, Denmark). Confluent cultures were washed twice with PBS and incubated for $72 \mathrm{~h}$ in $200 \mu \mathrm{l}$ medium containing $\left[{ }^{3} \mathrm{H}\right]$ thymidine ( $85 \mathrm{Ci} / \mathrm{mmol}$; $0.2 \mu \mathrm{Ci}$ per well; Amersham Biosciences, Little Chalfont, Bucks, UK) and the GnRH-I analog Triptorelin (100 nM; Ferring Arzneimittel, Kiel, Germany), the GnRH-II analog [D-Lys ${ }^{6}$ ]GnRH-II $(100 \mathrm{nM}$; Peptide Specialty Laboratories GmbH, Heidelberg, Germany) or $4 \mathrm{OH}$-tamoxifen $(0.25 \mu \mathrm{M})$. Because of the very short half-life of human GnRH-II in serum we used the superagonistic analog [D-Lys ${ }^{6}$ GnRH-II. The cells were then washed with ice-cold PBS twice, treated with 10\% trichloroacetic acid followed by $95 \%$ ethanol, and lysed with $400 \mu \mathrm{l} 0.25 \mathrm{M} \mathrm{NaOH}$ per well. Incorporated radioactivity was measured in a liquid scintillation counter (Beckman Coulter, Unterschleissheim, Germany).

\section{Quantification of phosphorylated EGF-R and MAPK (ERK1/2) activity}

Basal levels of phosphorylated EGF-R and activated MAPK (ERK1/2) were very low in all cell lines. Thus it was not possible to investigate any significant inhibitory effects of Triptorelin and [D-Lys ${ }^{6}$ ]GnRH-I without previous EGF-induced autophosphorylation of EGF-R or activation of MAPK. To induce autophosphorylation of EGF-R and activation of MAPK, cells were treated with human recombinant EGF (Sigma) at $100 \mathrm{nM}$ for $30 \mathrm{~min}$. However, exposure to EGF $(100 \mathrm{nM})$ for 5 and $15 \mathrm{~min}$ had no effect on autophosphorylation of EGF-R and activation of MAPK in our system with MCF-7 and T47D cells, so we focused further experiments on an activation time of 30 min with EGF. Triptorelin $(100 \mathrm{nM})$, [D-Lys ${ }^{6}$ ]GnRH-II $(100 \mathrm{nM})$ or specific inhibitor Iressa (28) (ZD1839, $4.5 \mu \mathrm{M}$; AstraZeneca, Wedel, Germany) was added 30 min prior to exposure to EGF. The cells were scraped from dishes with a rubber policeman, washed twice with PBS and then lysed on ice using a buffer $(\mathrm{pH}$ 6.8) containing $519 \mathrm{mM}$ dithiothreitol (Sigma), $69 \mathrm{mM}$ SDS, 0.1\% Triton X-100 (Sigma), $62.5 \mathrm{mM}$ Tris/ $\mathrm{HCl}$ and $75 \mathrm{nM}$ Bromphenol Blue. The cell lysates $\left(10^{4}\right.$ cells per $\mu \mathrm{l}$ lysate) were electrophoresed using SDS/PAGE (7.5\% acrylamide $/ N^{\prime}, N^{\prime}$-bis-methylene-acrylamamide; AppliChem GmbH, Darmstadt, Germany) and then transferred to nitrocellulose membranes according to the instructions of the suppliers (Hybond ${ }^{\mathrm{TM}}-\mathrm{ECL}^{\mathrm{TM}}$ nitrocellulose membrane; Amersham Biosciences). The nitrocellulose membranes were blocked in 5\% instant skimmed-milk powder, spray-dried (Naturaflor; Töpfer $\mathrm{GmbH}$, Dietmannsried, Germany) in TBST buffer $(137 \mathrm{mM} \mathrm{NaCl}, 2.7 \mathrm{mM} \mathrm{KCl}, 0.1 \%$ Tween 20 and
$25 \mathrm{mM}$ Tris/Cl, $\mathrm{pH}$ 7.4) for $1 \mathrm{~h}$ at room temperature, washed with TBST, and then incubated overnight by $4{ }^{\circ} \mathrm{C}$ with polyclonal rabbit anti-human phosphotyrosine antibody (Promega, Mannheim, Germany) or polyclonal rabbit anti-human/rat ACTIVE ${ }^{\mathrm{TM}}$ MAPK antibody pTEpY (anti-ERK1/2 polyclonal antibody; Promega) in a 1:200 or a 1:5000 dilution in TBST (Amersham Biosciences), respectively. After washing three times with TBST, specifically bound antibody was detected using the $\mathrm{ECL}^{\mathrm{TM}}$ Western-blotting analysis system (Amersham Biosciences). The bands were imaged by lightening and developing a radiographic film (Kodak BioMax MR film). Corresponding bands for phosphorylated EGF-R at $170 \mathrm{kDa}$ and MAPK (ERK1/2) at 42 and $44 \mathrm{kDa}$ were analysed using the Kodak 1D image system (Kodak, New Haven, CT, USA).

\section{Isolation of mRNA, cDNA synthesis and PCR amplification}

Polyadenylated RNA (poly(A) mRNA) was isolated from cells grown in monolayer using the Oligotex direct mRNA kit (Qiagen, Hilden, Germany). The concentration of poly(A) mRNA in each sample was determined by photospectrometry. First-strand cDNA was generated by reverse transcription of $1 \mu \mathrm{g}$ poly(A) mRNA using $\mathrm{p}(\mathrm{dT})_{15}$ primers (Roche Diagnostics) with Moloney murine leukaemia virus reverse transcriptase according to the instructions of the suppliers (Life Technologies, Karlsruhe, Germany). The cDNAs $(2 \mathrm{ng})$ were amplified in a $50 \mu \mathrm{l}$ reaction volume. The reaction mixture contained $10 \mathrm{mM}$ Tris/ $\mathrm{HCl}(\mathrm{pH} \mathrm{8.3)}$, $50 \mathrm{mM} \mathrm{KCl}, 1.5 \mathrm{mM} \mathrm{MgCl}_{2}, 200 \mu \mathrm{M}$ each dNTP, $1 \mu \mathrm{M}$ primers specific for human GnRH-I-R mRNA (29) (forward, 5'-CTG GCT GTG GAC ATC GCA TGT-3' reverse, $5^{\prime}$-ATG GCA GTC AGT GGC AGC AGA-3'), $1 \mu \mathrm{M}$ primers specific for the putative human GnRH-II-R mRNA (24) (forward, 5'-AGT CCA ATG GTA TGC TGG AGA-3'; reverse, 5'-ACC CGT GTC AGG GTG AAG AT- $3^{\prime}$ ), $1 \mu \mathrm{M}$ primers specific for human ER $\alpha$ (forward, 5'-AAT CTA GAT AAT CGA CGC CAG-3'; reverse, 5'-GTG TTT CAA CAT TCT CCC TCC TC-3'), $1 \mu \mathrm{M}$ primers specific for human ER $\beta$ (forward, 5'-TAG TGG TCC ATC GCC AGT TAT-3'; reverse, 5'-GGG AGC CAC ACT TCA CCA T-3'), $1 \mu \mathrm{M}$ primers specific for human EGF-R (forward, 5'-TGA TGG CTA GTG TGG ACA ACC-3'; reverse, 5'-CAT GAT ATT CTT TCT CTT CAG CA- $3^{\prime}$ ) or $1 \mu \mathrm{M}$ primers specific for human HER-2 oncogene product p185 (forward, 5'-GGC TGC TGG ACA TGG ACG AG-3'; reverse, 5'-GGG GCT GGG GCA GCC GCT C-3'), and $1.25 \mathrm{U}^{\prime}$ AmpliTaq Gold ${ }^{\circledR}$ polymerase (Applied Biosystems, Weiterstadt, Germany). The reaction was performed in an Applied Biosystems DNA thermal cycler 9600. 35 cycles of amplification of PCR were carried out: denaturation at $94^{\circ} \mathrm{C}$ for $30 \mathrm{~s}$, annealing for $60 \mathrm{~s}$ at individual temperature (GnRH-I-R, $61^{\circ} \mathrm{C}$; GnRH-II-R, $60^{\circ} \mathrm{C}$; HER-2 and EGF-R, $58^{\circ} \mathrm{C}$; ER $\alpha$ and $\mathrm{ER} \beta, 56^{\circ} \mathrm{C}$ ), followed by extension at $72^{\circ} \mathrm{C}$ for $60 \mathrm{~s}$. 
The PCR products were separated by gel electrophoresis in $1.5 \%$ agarose and visualized by ethidium bromide staining on a UV transilluminator. Corresponding bands were analyzed using the Kodak 1D image system.

\section{Comparative flow-cytometry analysis}

To analyse expression of GnRH-I-R and putative GnRHII-R, HER-2 gene product p185-expression, and expression of EGF-R in parental and resistance-developed sublines of MCF-7 and T47D cells, $10^{6}$ cells were resuspended in $50 \mu \mathrm{l}$ Hank's balanced salt solution (HBSS) containing $0.1 \%$ sodium azide, $1.5 \%$ Hepes, 2\% FCS and $50 \mu \mathrm{l}$ diluted primary antibody polyclonal rabbit anti-human GnRH-R-I or polyclonal rabbit anti-human GnRH-R-II (both 1:400; Peptide Research Laboratories), mouse anti-HER2 (1:10; TAB250; Zymed Laboratories, San Francisco, CA, USA) or monoclonal anti-EGF-R antibody produced in mouse (1:10; clone 29.1; Sigma) were added and incubated on ice for $1 \mathrm{~h}$. After washing, FITC-conjugated goat anti-mouse IgG or goat anti-rabbit IgG (both Sigma), respective to the first antibody used, was added at 1:20 dilution. The cell suspension was incubated on ice for $1 \mathrm{~h}$. Cells were washed in HBSS and immediately analysed by flow cytometry on FACScalibur equipment using Cellquest software (Becton Dickinson, Mountain View, CA, USA). Negative controls were performed by omission of primary antibodies. In each experiment $10^{5}$ cells were counted.

\section{Proliferation assays}

The time-course and dose-dependent proliferation experiments were performed as described in detail previously $(24,30)$. Briefly, 20000 cells of each cell line were plated in four-well cluster dishes (Nunc) and allowed to attach to the wells. After $24 \mathrm{~h}$ the medium was changed and $20 \mathrm{ml}$ PBS/BSA or appropriate dilutions of $4 \mathrm{OH}$-tamoxifen were added, resulting in final concentrations of $62.5-250 \mathrm{nM}$. Depletion of FCS resulted in complete de-adhesion and cell death in all cell lines on day 4 , so we supplemented the medium with 10\% stripped hormone-free FCS (Allgaeu BioTech Service, Goerisried, Germany). After $24 \mathrm{~h}$ of incubation the medium was changed. After 1, 2, 3 and 4 days the cells were counted in a Neubauer hemocytometer $(24,30)$.

\section{Apoptosis assays and cell-cycle analysis}

To quantify apoptosis and cell-cycle arrest we used a procedure similar to that described by Nicoletti et al. (31) based on detecting advanced DNA degradation. Briefly, a pellet containing $1 \times 10^{6}$ cells was gently resuspended in $500 \mu \mathrm{l}$ hypotonic fluorochrome solution containing $0.1 \%$ Triton $\mathrm{X}-100$, $0.1 \%$ sodium citrate and $50 \mu \mathrm{g} / \mathrm{ml}$ propidium iodide (Sigma). The cell suspensions were kept at $4{ }^{\circ} \mathrm{C}$ in the dark overnight before flow-cytometry analysis of cellular DNA content was performed using FACScalibur equipment with Cellquest software. In each experiment $10^{5}$ cells were counted. To analyse apoptosis induced by 40H-tamoxifen (250 nM), Triptorelin (100 nM), [DLys $\left.^{6}\right] \mathrm{GnRH}-\mathrm{II}(100 \mathrm{nM})$ or Iressa $(4.5 \mu \mathrm{M})$, drugs or vehicle were added to the medium as described above. Cells were harvested after $72 \mathrm{~h}$ and prepared as described for further analysis.

\section{Statistical analysis}

All experiments were performed at least three times in different passages of the respective cell lines. Unless otherwise indicated, results are expressed as percentages of the respective controls and were pooled before being tested for statistically significant differences by one-way analysis of variance, followed by a Newman-Keuls' test for the comparison of individual groups.

\section{Results}

\section{Direct antiproliferative effects of GnRH-I analog Triptorelin and GnRH-II analog [D-Lys $\left.{ }^{6}\right]$ GnRH-II}

To show direct antiproliferative effects we compared $\left[{ }^{3} \mathrm{H}\right]$ thymidine incorporation after $72 \mathrm{~h}$ of exposure to GnRH-I analog Triptorelin and GnRH-II analog [DLys $\left.^{6}\right] \mathrm{GnRH}-\mathrm{II}$, both at the well-established concentration of $100 \mathrm{nM}$, with exposure to $4 \mathrm{OH}$-tamoxifen (250 nM) in MCF-7 and T47D cells. In MCF-7 cells $4 \mathrm{OH}$-tamoxifen reduced $\left[{ }^{3} \mathrm{H}\right]$ thymidine incorporation from $100 \pm 15.4 \%$ in untreated control cells to $53.3 \pm 13.2 \%$ ( $P<0.001$ compared with the control $)$. Triptorelin reduced $\left[{ }^{3} \mathrm{H}\right]$ thymidine-incorporation in these cells to $64.9 \pm 12.8 \%(P<0.001)$ and [DLys $\left.{ }^{6}\right]$ GnRH-II to $55.9 \pm 9.7 \%(P<0.001)$. In T47D cells $4 \mathrm{OH}$-tamoxifen reduced $\left[{ }^{3} \mathrm{H}\right]$ thymidine incorporation from $100 \pm 14.1 \%$ in untreated control cells to $34.7 \pm 18.9 \%(P<0.001)$. Triptorelin reduced $\left[{ }^{3} \mathrm{H}\right]$ thymidine incorporation in these cells to $45.9 \pm 16.7 \%$ and [D-Lys ${ }^{6}$ ]GnRH-II to $49.7 \pm 13 \%$ (both $P<0.001$ compared with the control; Fig. 1).

\section{Effects of Triptorelin and [D-Lys ${ }^{6}$ ]GnRH-II on EGF-induced autophosphorylation of EGF-R}

We compared effects of Triptorelin and [D-Lys ${ }^{6}$ ]GnRH-II on EGF-induced EGF-R tyrosine autophosphorylation to the effects of the specific PTK inhibitor Iressa in MCF-7 and T47D cells. The amount of detectable phosphorylated EGF-Rs in quiescent cells was very low in our assay. Treatment with human recombinant EGF 

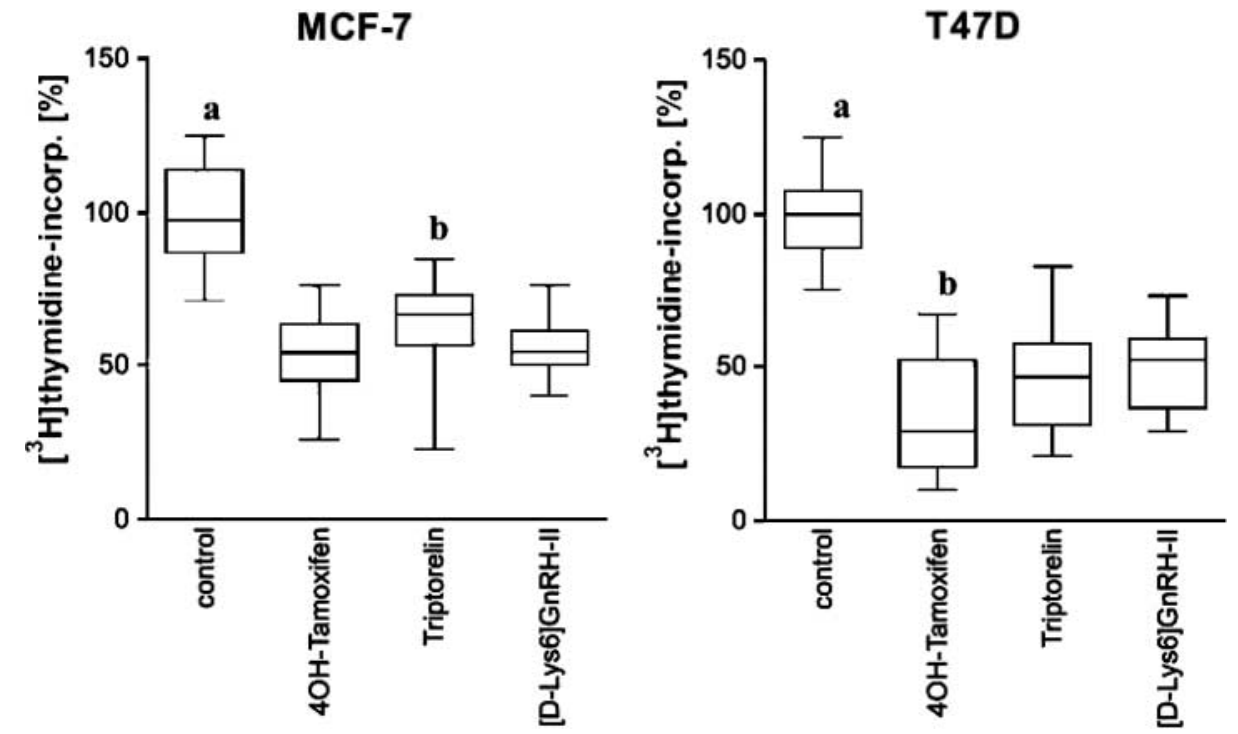

Figure $1\left[{ }^{3} \mathrm{H}\right]$ Thymidine incorporation into human breast cancer MCF-7 and T47D cells after $72 \mathrm{~h}$ of exposure to $4 \mathrm{OH}$-tamoxifen $(250 \mathrm{nM})$, Triptorelin or [D-Lys ${ }^{6}$ ] GnRH-II (both $100 \mathrm{nM}$ ). Boxes and whiskers represent median, S.E. and maximum plus minimum of data obtained from four independent experiments in four different passages of the cell lines. Results were tested by one-way analysis of variance, followed by a Newman-Keuls' test for the comparison of individual groups. MCF-7, ${ }^{a} P<0.001$ compared with all other groups; ${ }^{\mathrm{b}} P<0.01$ compared with $4 \mathrm{OH}$-tamoxifen and [D-Lys ${ }^{6}$ GnRH-II; T47D, ${ }^{\mathrm{a}} P<0.001$ compared with all other groups; ${ }^{\mathrm{b}} P<0.01$ compared with Triptorelin and $\left[\mathrm{D}-\mathrm{Lys}^{6}\right] \mathrm{GnRH}-\mathrm{II}$.

(100 nM) for 30 min resulted in a significant increase of phosphorylated EGF-Rs in MCF-7 cells to $180 \pm 33 \%$ and in T47D cells to $226.3 \pm 47.4 \%$, as compared with quiescent cells (100\%). Pretreatment with Iressa $(4.5 \mu \mathrm{M})$ for $30 \mathrm{~min}$, used as a positive control, completely abolished the effects of EGF on EGF-R autophosphorylation in MCF-7 and T47D cells. In MCF-7 and T47D cells pretreatment with Triptorelin or [DLys $^{6}$ ]GnRH-II (both $100 \mathrm{nM}$ ) for $30 \mathrm{~min}$ showed almost similar effects to Iressa (MCF-7/EGF + Triptorelin, $110.7 \pm 27.6 \%, P<0.05$ compared with EGF; MCF-7/EGF + [D-Lys $\left.{ }^{6}\right]$ GnRH-II, $111.7 \pm 18.6 \%$, $P<0.01 ; \quad$ T47D/EGF + Triptorelin, $\quad 73 \pm 44.8 \%$, $P<0.01 ;$ T47D/EGF + [D-Lys $^{6}$ ]GnRH-II, 56士43.1\%, $P<0.01$; Fig. 2). Experiments in the developed sublines MCF-7-TR and T47D-TR yielded comparable results (data not shown).

\section{Effects of Triptorelin and [D-Lys ${ }^{6}$ ]GnRH-II on EGF-induced MAPK (ERK1/2) activation}

We then compared effects of Triptorelin and [DLys $\left.^{6}\right] \mathrm{GnRH}$-II on EGF-induced MAPK (ERK1/2) activity to the effects of Iressa. Treatment with EGF (100 nM) for $30 \mathrm{~min}$ resulted in a significant increase of MAPK activity in MCF-7 (164.7 $\pm 9.5 \%)$ and T47D $(222.3 \pm 33.6 \%)$ cells, as compared with quiescent cells. Pretreatment with Iressa $(4.5 \mu \mathrm{M})$ for $30 \mathrm{~min}$ completely abolished the effects of EGF on MAPK activity in MCF-7 and T47D cells. In MCF-7 and T47D cells pre-

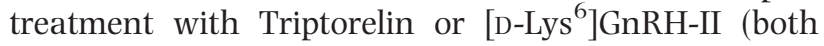

$100 \mathrm{nM}$ ) for $30 \mathrm{~min}$ showed comparable effects to Iressa (MCF-7/EGF + Triptorelin, 98.3 $44 \%, P<0.01$ compared with EGF; MCF-7/EGF $+\left[\right.$ D-Lys $\left.^{6}\right] \mathrm{GnRH}-\mathrm{II}$, $97.3 \pm 19.9 \%, \quad P<0.01 ; \quad$ T47D/EGF + Triptorelin, $69.3 \pm 33.1 \%, P<0.001 ;$ T47D/EGF $+\left[\right.$ D-Lys $\left.^{6}\right] \mathrm{GnRH}-$ II: $65.3 \pm 48.8 \%, P<0.01$; Fig. 3). Experiments in the developed sublines MCF-7-TR and T47D-TR yielded comparable results. These cells did not show significant increased basal levels of MAPK activity compared with parental cells (data not shown).

\section{Comparative characterization of parental MCF-7 and T47D cells and developed 4OH- tamoxifen-resistant sublines MCF-7-TR and T47D-TR}

The developed sublines with secondary resistance to the growth-inhibitory effect of $4 \mathrm{OH}$-tamoxifen were analysed for their expression of ER $\alpha$ and $\mathrm{ER} \beta$, HER-2 gene product p185, EGF-R, GnRH-I-R and GnRH-II-R using reverse transcriptase (RT)-PCR. The cell-surface expression of p185, EGF-R, GnRH-I-R and GnRH-II-R was analysed by flow cytometry. In MCF-7-TR cells using RT-PCR we found a 3-fold up-regulation of mRNA expression of ER $\alpha$, HER-2/p185 and EGF-R compared with parental cells. Expression of ER $\beta$ was also increased slightly, but not significantly. There was no change in expression of mRNA for GnRH-I-R and GnRH-II-R (Fig. 4). Cell-surface expression of p185 and EGF-R were increased slightly in MCF-7-TR cells, whereas expression of GnRH-I-R and GnRH-II-R was 


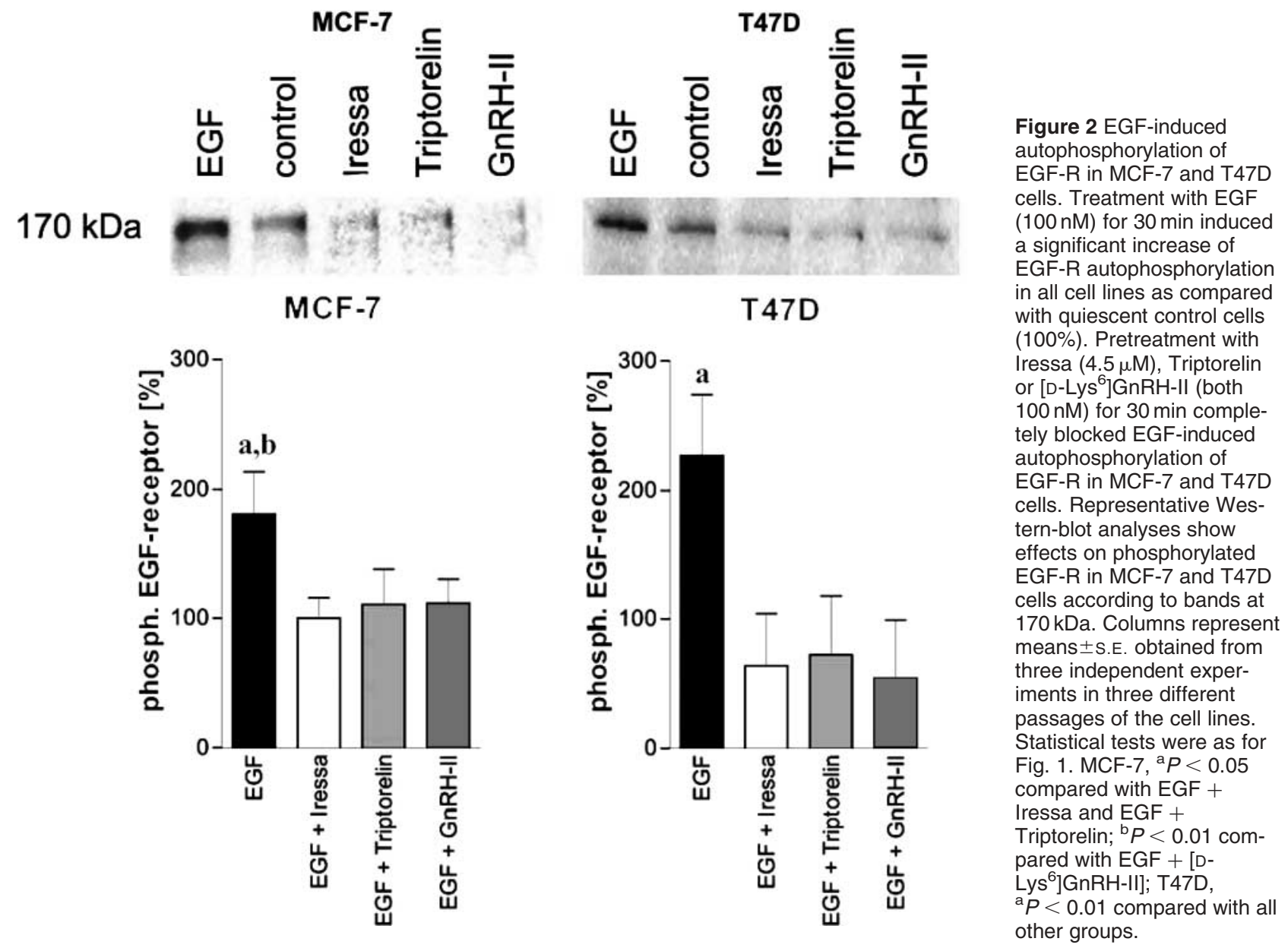

decreased slightly compared with parental MCF-7 cells (Fig. 5). In T47D-TR cells using RT-PCR we found a 2-fold up-regulation of mRNA-expression of HER-2 and a slightly but not significantly increased expression of EGF-R compared with parental T47D cells. Expression of mRNA for $\mathrm{ER} \alpha$, ER $\beta$ and GnRH-II-R was clearly downregulated in T47D-TR cells. There was no significant difference in expression of mRNA for GnRH-I-R in T47D cells and the developed subline (Fig. 4). Cell-surface expression of p185 was clearly increased in T47DTR cells, whereas expression of EGF-R, GnRH-I-R and GnRH-II-R was decreased, compared with parental T47D cells (Fig. 5).

We then tested the effects of Triptorelin and [DLys $\left.^{6}\right]$ GnRH-II on EGF-induced autophosphorylation of EGF-R and MAPK (ERK1/2) activity in the developed sublines.

\section{Effects of 4OH-tamoxifen on proliferation in parental and resistant MCF-7 and T47D cells}

In parental MCF-7 and T47D cells 4OH-tamoxifen showed time- and dose-dependent antiproliferative effects (Fig. 6). In MCF-7-TR cells 4OH-tamoxifen showed strong proliferative effects with a maximum on day 3 compared with control cells without 40H-tamoxifen. This effect may be explained by a lower proliferation rate in control cells due to depletion of $4 \mathrm{OH}$-tamoxifen, which is regularly supplemented to the medium when MCF-7-TR cells are kept in culture. The proliferative effect of 4OH-tamoxifen in MCF-7-TR cells disappeared on day 4 (Fig. 6). In T47D-TR cells 4OH-tamoxifen had no significant effect on proliferation up to day 3 compared with control cells. However, depletion of 40H-tamoxifen resulted in complete de-adhesion of the control T47D-TR cells on day 4 and cells showed morphological criteria of apoptosis, so cells treated with $4 \mathrm{OH}$-tamoxifen cannot be quantified as percentages of untreated control cells on day 4 (Fig. 6).

\section{Effects of Triptorelin, [D-Lys $\left.{ }^{6}\right] G n R H-I I$ and Iressa on apoptosis induced by $40 \mathrm{H}$ - tamoxifen-induced in parental and resistance- developed MCF-7 and T47D cells}

In MCF-7 cells treatment with 40H-tamoxifen $(250 \mathrm{nM})$ for $72 \mathrm{~h}$ increased apoptosis from 
MCF-7
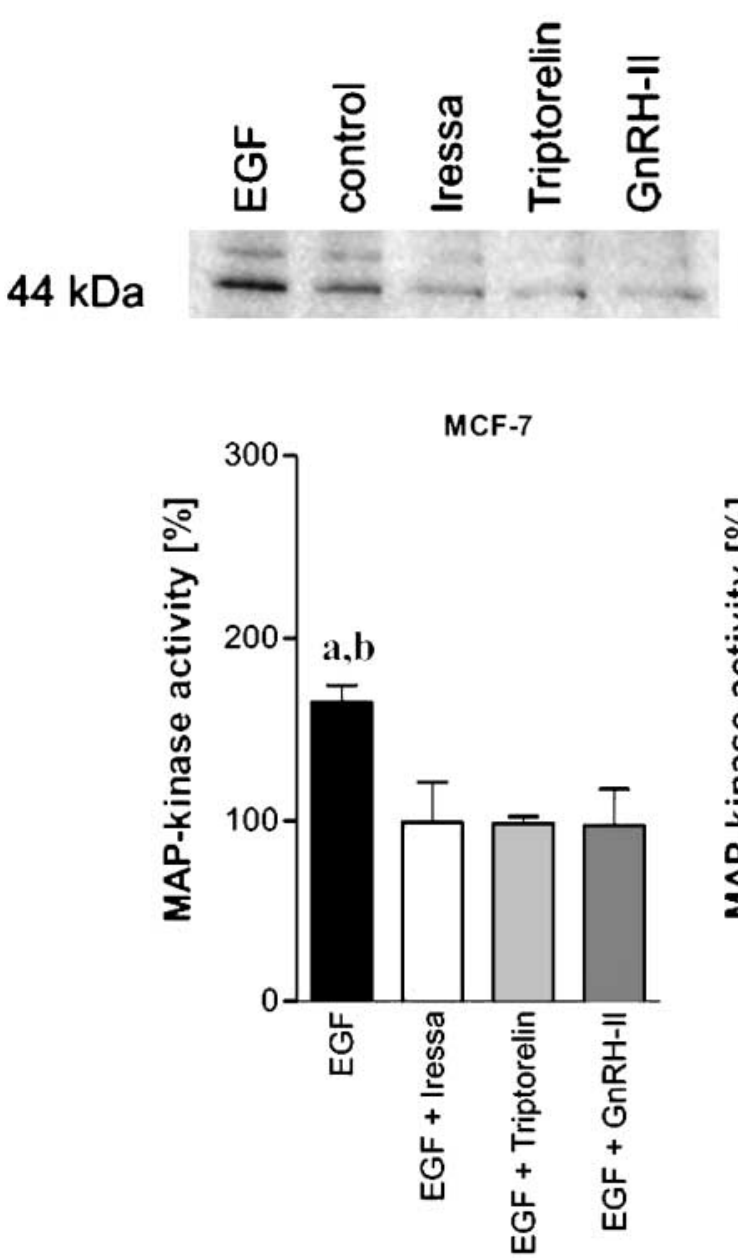

T47D

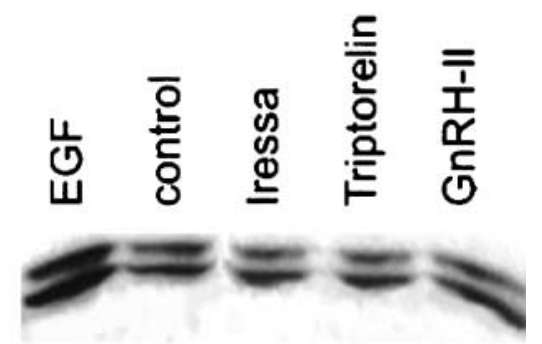

T47D

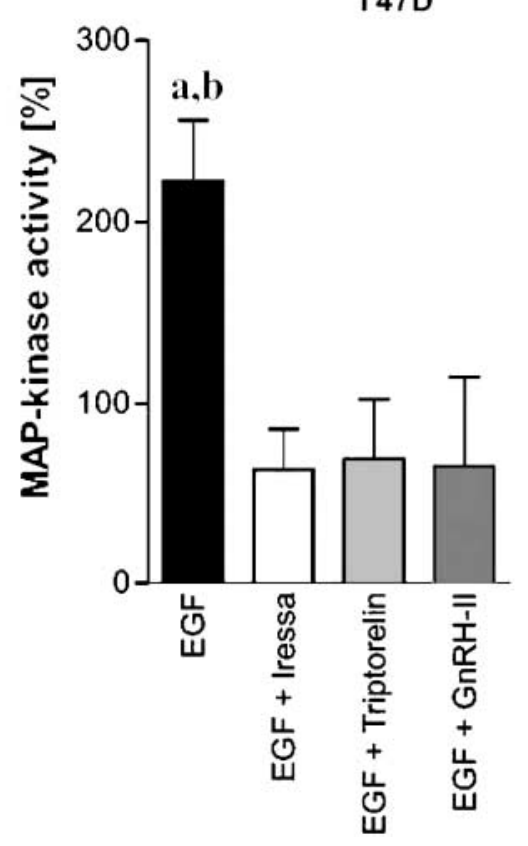

Figure 3 MAPK (ERK1/2) activity in MCF-7 and T47D cells. Treatment with EGF $(100 \mathrm{nM})$ for 30 min significantly increased MAPK activity in all cell lines as compared with quiescent control cells (100\%). Pretreatment with Iressa $(4.5 \mu \mathrm{M})$, Triptorelin or [DLys $\left.{ }^{6}\right] \mathrm{GnRH}-\mathrm{II}$ (both $100 \mathrm{nM}$ ) for 30 min completely blocked EGF-induced MAPK activity in all cell lines. Representative Western-blot analyses show effects on activated MAPK in MCF-7 and T 47D cells according to bands at 42 and $44 \mathrm{kDa}$. Columns represent means \pm S.E. obtained from three independent experiments in three different passages of the cell lines. Statistical tests were as for Fig. 1. MCF-7, ${ }^{a} P<0.01$ compared with EGF + Triptorelin and EGF + [D-Lys $\left.{ }^{6}\right]$ GnRH-II, ${ }^{\mathrm{b}} P<0.001$ compared with EGF + Iressa; T47D, ${ }^{a} P<0.01$ compared with EGF + Iressa and EGF + [D-Lys $\left.{ }^{6}\right] \mathrm{GnRH}$-II, ${ }^{\mathrm{b}} P<0.001$ compared with EGF + Triptorelin.
$15.7 \pm 2.5 \%$ (spontaneous apoptosis rate in untreated control cells) to $25.7 \pm 1.5 \%$. Treatment with Triptorelin or [D-Lys $\left.{ }^{6}\right]$ GnRH-II (both $100 \mathrm{nM}$ ) for $72 \mathrm{~h}$ did not significantly increase apoptosis rate in these cells. Addition of Triptorelin or [D-Lys $\left.{ }^{6}\right] \mathrm{GnRH}-\mathrm{II}$ (both $100 \mathrm{nM})$ to $40 \mathrm{H}$-tamoxifen was without significant effect on apoptosis induced by $4 \mathrm{OH}$-tamoxifen. Comparable results were obtained in experiments with T47D cells (Fig. 7). In the sublines resistant to antiproliferative effects of 4OH-tamoxifen, MCF-7-TR and T47DTR, 4OH-tamoxifen $(250 \mathrm{nM})$ had no significant effect on apoptosis rate. Treatment with Triptorelin or [DLys $^{6}$ ]GnRH-II (both $100 \mathrm{nM}$ ) for $72 \mathrm{~h}$ did not significantly increase apoptosis compared with spontaneous apoptosis rate of untreated control cells. In MCF-7-TR cells simultaneous treatment with 40H-tamoxifen $(250 \mathrm{nM})$ and Triptorelin or $\left[\mathrm{D}-\mathrm{Lys}^{6}\right] \mathrm{GnRH}-\mathrm{II}$ (both $100 \mathrm{nM}$ ) significantly increased apoptosis from $12.3 \pm 4.0 \%$ (spontaneous rate in untreated control cells) to $23.3 \pm 6.7$ and $25 \pm 5.3 \%$, respectively. In T47D-TR cells simultaneous treatment with 4OHtamoxifen $(250 \mathrm{nM})$ and Triptorelin or $\left[\mathrm{D}-\mathrm{Lys}^{6}\right] \mathrm{GnRH}-$
II (both $100 \mathrm{nM}$ ) significantly increased apoptosis from $10.7 \pm 3.1 \%$ (spontaneous rate in untreated control cells) to $22.0 \pm 4.4$ or $22.0 \pm 3.6 \%$, respectively (Fig. 7). Exposure to Iressa $(4.5 \mu \mathrm{M})$ for $72 \mathrm{~h}$ did not increase apoptosis in parental MCF-7 and T47D cells or in the developed sublines. Simultaneous treatment with Iressa had no effect on apoptosis induced by 4OH-tamoxifen in parental cells and in the developed sublines (data not shown). We then analysed effects of Iressa on cell-cycle arrest in MCF-7 and T47D cells and in the developed sublines MCF-7-TR and T47DTR. In all cell lines we found a tendency for cell-cycle arrest in the $G_{1}$ phase when cells were treated with Iressa $(4.5 \mu \mathrm{M})$ alone or in combination with $4 \mathrm{OH}-$ tamoxifen $(0.25 \mu \mathrm{M})$ for $72 \mathrm{~h}$, but these effects were not statistically significant (data not shown).

\section{Discussion}

Previous work and our present data demonstrate direct antiproliferative effects of GnRH in GnRH-R- 

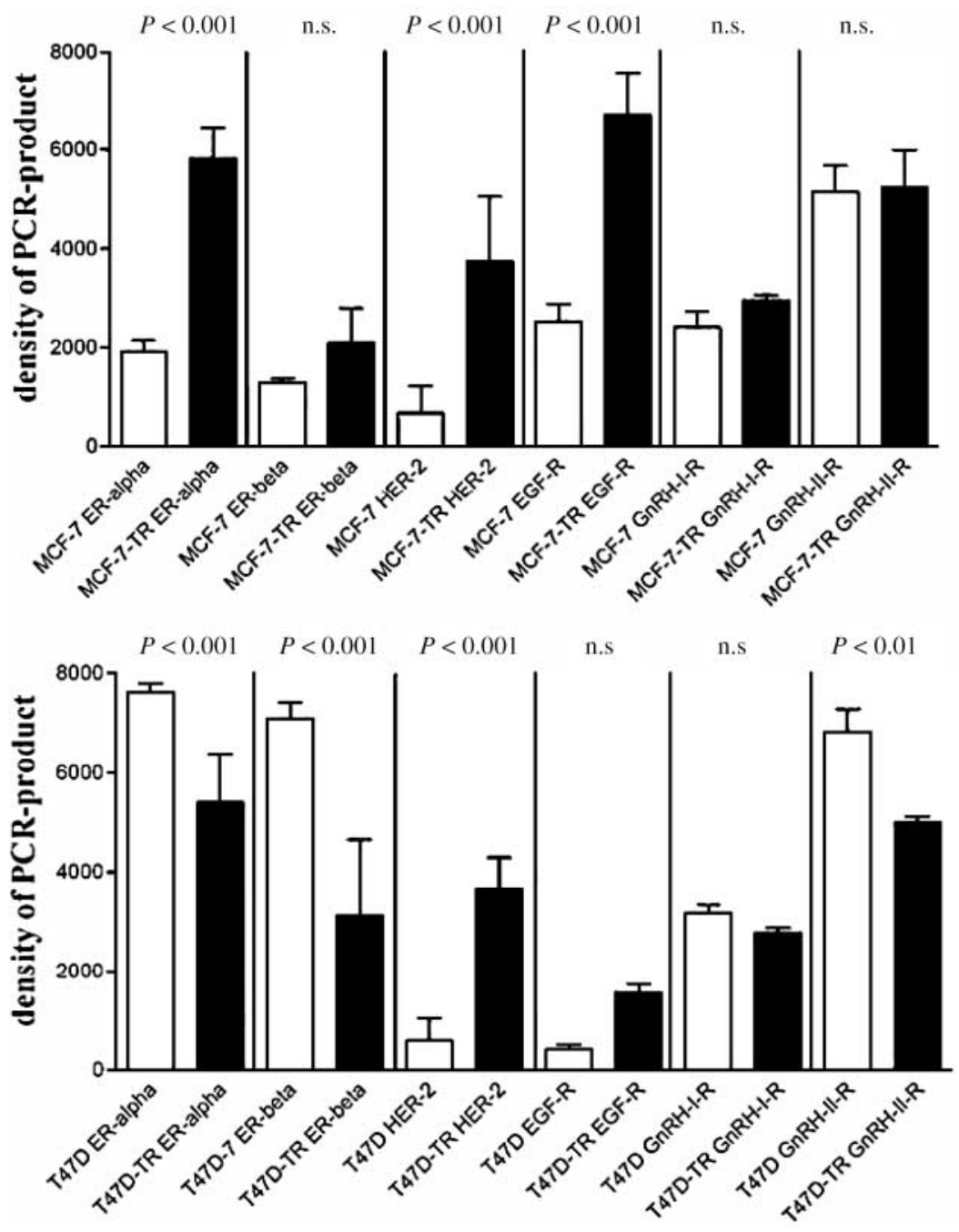

Figure 4 RT-PCR analysis showing comparative semi-quantitative expression of mRNA of ER $\alpha$, ER $\beta$, HER-2 oncogene product p185, EGF-R, GnRH-I-R and GnRH-II-R in parental MCF-7 and T47D cells and in the developed sublines MCF-7-TR and T47DTR. Columns represent means \pm S.E. obtained from three independent experiments in three different passages of the cell lines. Statistical tests were as for Fig. 1; n.s., not significant.

positive human breast cancer cells $(5-8,12)$. The antiproliferative effect of the GnRH-I analog Triptorelin and the GnRH-II analog [D-Lys ${ }^{6}$ GnRH-II in MCF-7 and T47D cells was not due to increased apoptosis. These data are in good accordance with previous results in human ovarian cancer cells, in which GnRH analogs induced JunD DNA binding and an extended cell cycle, but did not induce apoptosis (20). In our system Triptorelin and [D-Lys $\left.{ }^{6}\right] \mathrm{GnRH}-\mathrm{II}$ interfered with EGF-induced signal transduction and completely inhibited EGF-induced autophosphorylation of EGF-R and induction of MAPK (ERK1/2) activity in MCF-7 and T47D cells. In the sublines of MCF-7 and T47D cells that were developed to be resistant to the antiproliferative effects of 4OH-tamoxifen (MCF-7-TR and T47D-TR) treatment with Triptorelin and [DLys $^{6}$ ]GnRH-II reinstalled 4OH-tamoxifen sensitivity, as assessed by induction of apoptosis. In MCF-7-TR cells exposition to $40 \mathrm{H}$-tamoxifen showed proliferative effects compared with cells with depletion of $4 \mathrm{OH}-$ tamoxifen, whereas in T47D cells depletion or exposure to increased concentrations of $40 \mathrm{H}$-tamoxifen had no effect on proliferation. In the developed sublines we found a slight down-regulated expression of GnRH-I-R and GnRH-II-R, whereas expression of the HER-2 oncogene product p185 was increased markedly in both cell lines. The expression of mRNA for EGF-R was also increased in MCF-7-TR and T47D-TR, but the cell-surface expression of EGF-R was hardly altered compared with parental cells. Although MCF-7-TR and T47D-TR showed slightly decreased cell-surface expression of GnRH-I-R and GnRH-II-R, exposure to Triptorelin and [DLys ${ }^{6}$ GnRH-II showed comparable effects on EGFinduced autophosphorylation of EGF-R and MAPK (ERK1/2) activation as in parental cells. Iressa (gefitinib/ZD1839) strongly inhibited EGF-induced autophosphorylation of EGF-R and MAPK (ERK1/2) activation in all cell lines but had no effect on apoptosis induced by $40 \mathrm{OH}$-tamoxifen. In our system treatment with Iressa resulted in marginally increased cell-cycle arrest in the $G_{1}$ phase. 


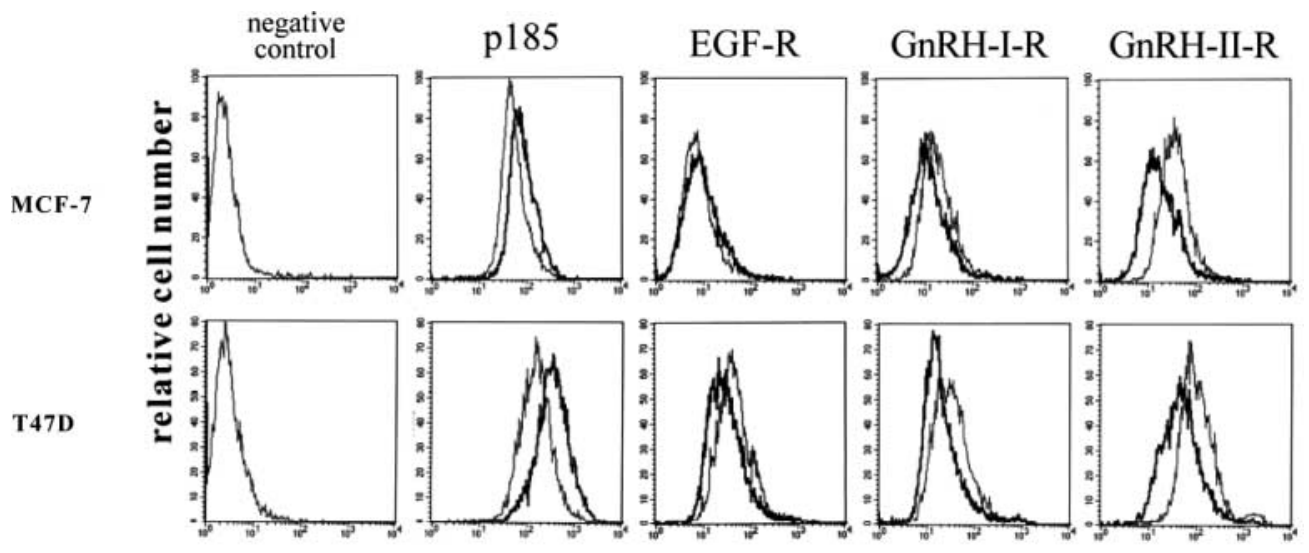

\section{fluorescence}

Figure 5 Comparative flow-cytometry analysis showing surface expression of HER-2 oncogene product p185, EGF-R, GnRH-I-R and GnRH-II-R in parental MCF-7 and T47D cells (thin lines) and in the developed sublines MCF-7-TR and T47D-TR (thick lines). Values for mean fluorescence of surface expression (negative control, $<10$ ) were as follows: HER-2 oncogene product p185, 60.2 (MCF-7) versus 92.8 (MCF-7-TR), 187.1 (T47D) versus 427.7 (T47D-TR); EGF-R, 10.1 (MCF-7) versus 12.8 (MCF-7-TR), 61.3 (T47D) versus 44.0 (T47D-TR); GnRH I-R, 23.0 (MCF-7) versus 15.7 (MCF-7-TR), 50.3 (T47D) versus 32.0 (T47D-TR); GnRH II-R, 46.5 (MCF-7) versus 22.6 (MCF-7-TR), 157.6 (T47D) versus 69.0 (T47D-TR). Histograms show representative data obtained from three independent flow cytometry analysis experiments in three different passages of the cell lines.

MCF-7

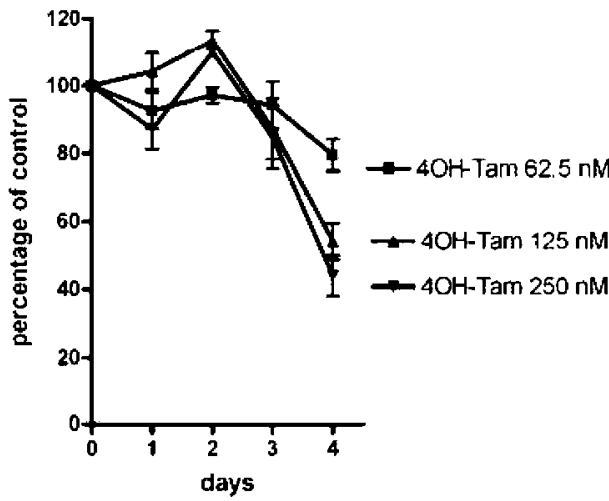

MCF-7-TR

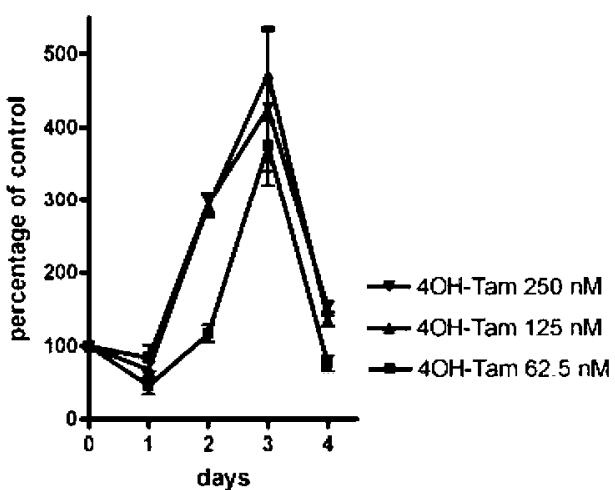

T47D

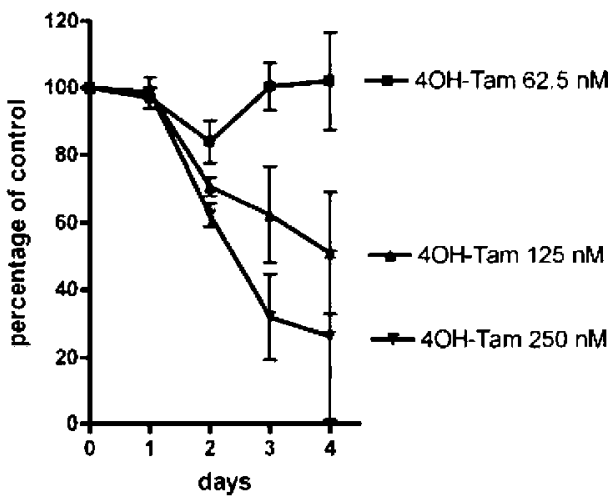

T47D-TR

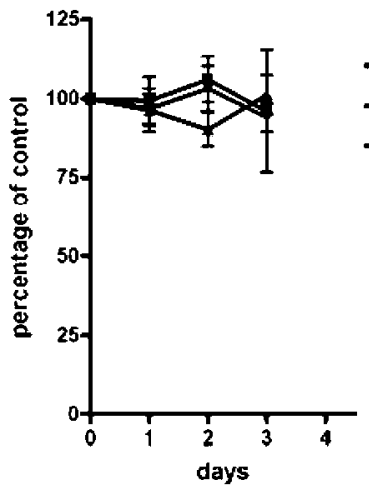

Figure 6 Proliferation assays in parental and resistant MCF-7 and T47D cells with exposure to 4OH-tamoxifen in concentrations of 62.5-250 nM. The effects of $4 \mathrm{OH}$-tamoxifen on cell proliferation are expressed as percentages of untreated control cells (100\%). Graphs represent means \pm S.E. obtained from three independent experiments in three different passages of the cell lines. 


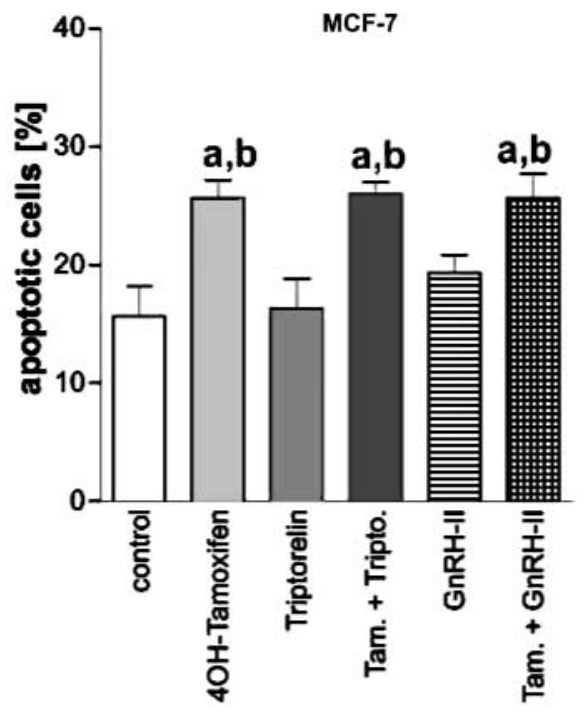

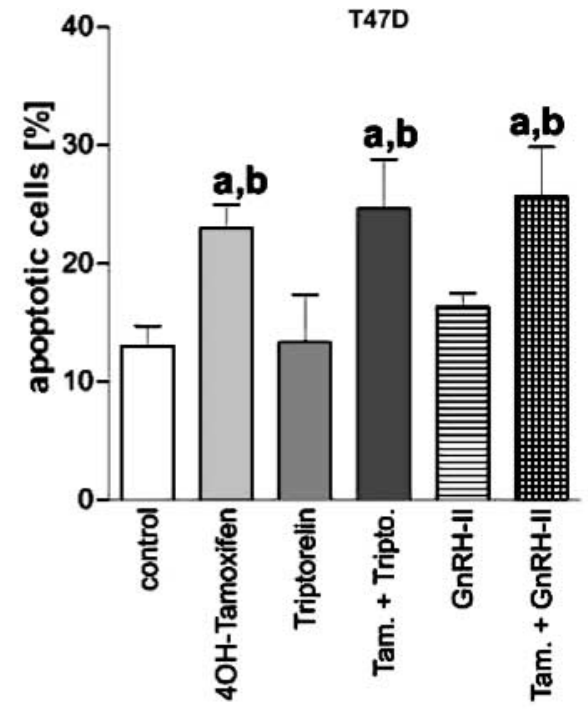

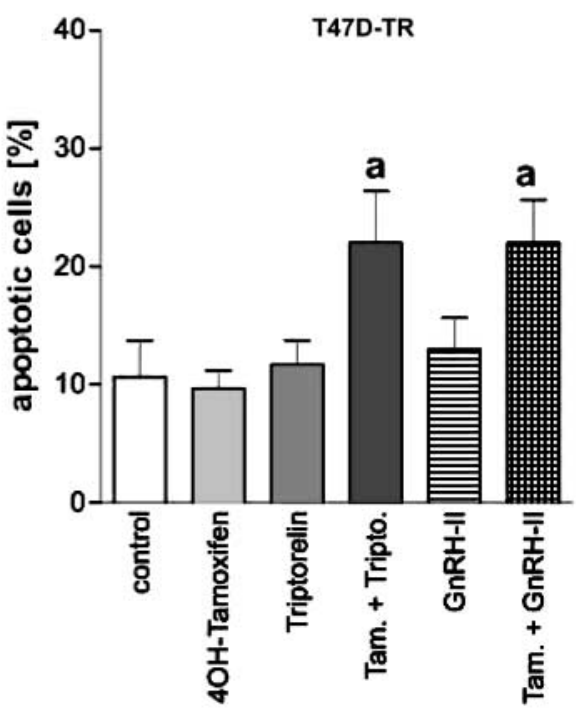

Figure 7 Quantification of apoptosis in parental and $4 \mathrm{OH}$ tamoxifen-resistant MCF-7 and T47D cells after $72 \mathrm{~h}$ exposure to $4 \mathrm{OH}$-tamoxifen $(250 \mathrm{nM})$, Triptorelin or [D-Lys $\left.{ }^{6}\right] \mathrm{GnRH}-\mathrm{II}$ (both $100 \mathrm{nM}$ ), or GnRH analogs in combination with $4 \mathrm{OH}$ tamoxifen. Columns represent means \pm S.E. obtained from three independent experiments in three different passages of the cell lines. Statistical tests were as for Fig. 1. MCF-7, ${ }^{\text {a }} P<0.001$ compared with control and Triptorelin, ${ }^{\mathrm{b}} \mathrm{P}<0.01$ compared with [DLys $\left.{ }^{6}\right] \mathrm{GnRH}-\mathrm{II} ;$ T47D, ${ }^{\mathrm{a}} P<0.01$ compared with control and Triptorelin, ${ }^{\mathrm{b}} P<0.05 \mathrm{com}$ pared with $\left[\mathrm{D}-\mathrm{Ly} \mathrm{s}^{6}\right] \mathrm{GnRH}-\mathrm{II}$; MCF-7-TR, ${ }^{\text {a }} P<0.05$ compared with control, $4 \mathrm{OH}$-tamoxifen, Triptorelin and [DLys ${ }^{6}$ ]GnRH-II; T47D-TR, ${ }^{a} P<0.01$ compared with control, 4OH-tamoxifen, Triptorelin and $\left[\mathrm{D}-\mathrm{Lys} \mathrm{s}^{6}\right] \mathrm{GnRH}-\mathrm{II}$.
Receptors for GnRH I are frequently expressed by breast cancers $(1-4)$. Direct antiproliferative effects of GnRH-I analogs in human breast cancer cells in vitro or xenotransplanted into nude mice are mediated at least in part by an antagonism of growth-promoting factors, such as estradiol, EGF and IGF (8-12), and inhibit estradiol-induced serum-response element (SRE) activation and c-fos expression (18). We now demonstrate that the previously described GnRH-I-mediated inhibition of EGF-induced tyrosine phosphorylation of EGF-R and down-regulation of MAPK (ERK-1/2) activity in human ovarian and endometrial cancers $(17,30)$ also occur in human breast cancers.

Expression of mRNA for GnRH-II-R has been described in non-human primates and in human tissues. Until now, however, attempts to clone or sequence a functional full-length receptor have not yet been successful $(24,32-35)$. In mammals, GnRH-II-Rs have been found to be more widely expressed in the body than GnRH-I-Rs, suggesting that GnRH-II may have various functions (36). The functional GnRH-II-R is expressed in various splice variants (37), but the human type II receptor gene homolog carries a frameshift mutation and a premature stop codon, findings suggesting that a full-length type II receptor does not exist in humans (38). The antiproliferative effects of GnRH-II in human endometrial and ovarian cancer cells persist in cells after knockout of the GnRH-I-R, whereas the antiproliferative effect of GnRH-I agonist Triptorelin was completely abrogated in these cells, implying that the antiproliferative effects of GnRH-II are not mediated through the GnRH-I-R (25). Enomoto et al. (39) confirmed effects of GnRH-II in HHUA, 
DU145, TSU-Pr1 and Jurkat cells with knocked-down GnRH-I-R and suggested functionality of a human type II GnRH-R splice variant. We recently identified a $43 \mathrm{kDa}$ cell-membrane protein with GnRH-II-R antigenicity in human placenta, and endometrial, ovarian and prostate cancer cells by a polyclonal rabbit antihuman GnRH-II-R antiserum, which was generated using a peptide corresponding to the third extracellular domain of the GnRH-II-R. The $43 \mathrm{kDa}$ band detected in Western-blot analysis was identified as a specific GnRH-II-binding site by photoaffinity labeling using ${ }^{125}$ I-labeled (4-azidobenzoyl)-N-hydroxysuccinimid[D-Lys ${ }^{6}$ GnRH-II (40). Using this polyclonal rabbit anti-human GnRH-II-R antiserum, we detected GnRH-II-R antigenicity at the cell surface of human MCF-7 and T47D breast cancer cells. In these cells the GnRH-II analog [D-Lys ${ }^{6}$ ]GnRH-II had antiproliferative effects, inhibited EGF-induced autophosphorylation of EGF-R and activation of MAPK (ERK1/2). Kim et al. (41) showed antiproliferative effects of GnRH-II in human ovarian cancer cells at the same concentration $(100 \mathrm{nM})$, although they described activation of MAPK (ERK1/2) by GnRH-II. We now confirm the described interference of GnRH-II with the ERK1/2 pathway by attenuating EGF-stimulated MAPK activation.

Estrogen-dependent breast cancers can progress from an antiestrogen-sensitive to an antiestrogenresistant state. HER-2/p185 or EGF-R overexpression and heterodimerization of members of the c-erbB family in human breast cancers results in activation of MAPK (ERK1/2), which phosphorylates Ser-118 in the ER, leading to ligand-independent ER activation with loss of the inhibitory effect of tamoxifen on ERmediated transcription $(26,27,42,43)$. Tamoxifen recruits transcriptional corepressors to the AF-2 region in the hormone-binding domain of the ER to block ER-mediated transcription (44). HER-2/p185induced hyperactivity of MAPK inhibits tamoxifenmediated association of ER with nuclear receptor corepressor (N-CoR) in antiestrogen-resistant cells. Selective inhibition of MAPK by U0126 or AG1478 restores this association and abrogates antiestrogen-resistance in human breast cancers (26). HER-2 signaling activates the same signaling pathways activated by EGF and both receptors contribute to transformation in a cooperative manner (reviewed in (45)). Expression of EGF-R is found in more than $60 \%$ of human breast cancers and is inversely related to expression of ER and is a negative predictor for response to endocrine therapy in vitro and in vivo $(27,46,47)$. Knowlden et al. (27) demonstrated reduced MAPK (ERK1/2) activity in developed tamoxifen-resistant MCF-7 cells, which generated a range of EGF-R specific ligands and transforming growth factor, after exposure to Iressa, trastuzumab (Herceptin) or MAPK-inhibitor PD098059, leading to growth inhibition in these cells. This indicates an autocrine release and action of EGF-R specific ligands inducing preferential EGF-R/HER-2 dimerization and downstream activation of the ERK pathway in tamoxifen-resistant cells. Gee et al. (48) showed that co-treatment with tamoxifen and Iressa or fulvestrant and Iressa is superior to treatment with tamoxifen alone in MCF-7 cells, and the combined treatment probably prevents secondary resistance to antiestrogens. In these cells increased EGF-R expression and MAPK activity induced by long-term administration of tamoxifen was prevented by co-treatment with Iressa, whereas Iressa alone was ineffective on growth inhibition (48). The aim of our study was to evaluate the effects of Iressa in comparison to Triptorelin and [D-Lys $\left.{ }^{6}\right]$ GnRH-II on apoptosis induced by 4 $\mathrm{OH}$-tamoxifen up to $72 \mathrm{~h}$, which was not increased by Iressa. We did not quantify growth inhibition by Iressa, which occurs significantly after 15 days in culture (48) and probably would occur in our cells after long-term administration too, indicated by the marginal effects of cell-cycle arrest in the $G_{1}$ phase. It is likely that the downstream activation of the ERK pathway in our system of $40 \mathrm{H}$-tamoxifen-resistant cells is not mediated preferentially by EGF-R/HER-2 dimerization, which can be blocked by Iressa or trastuzumab (27). The mechanism of tamoxifen resistance in our cell lines is not yet clear, since we cannot explain the up-regulation of mRNA expression of ER $\alpha$ and ER $\beta$ in MCF-7-TR cells, whereas in T47D-TR cells mRNA expression of $E R \alpha$ and $E R \beta$ was down-regulated. Although we could not describe hyperactivity of MAPK in our developed sublines, it is likely that Triptorelin and [D-Lys ${ }^{6}$ ] GnRH-II shows comparable activity to the specific MAPK inhibitor AG1478, which enhanced tamoxifen action in resistant MCF-7 cells (26). It is probable that increased expression of p185 and downstream activation of the ERK pathway are not the only mechanisms of tamoxifen resistance in our cell lines. Recently Jordan et al. (49) showed increased levels of phosphorylated phosphoinositide 3-kinase signaling component Akt1 in MCF-7 cells with developed tamoxifen resistance, which was activated by the ligands of the EGF-R, EGF and transforming growth factor $\alpha$ (TGF- $\alpha$ ); in addition, Akt1 activation could be inhibited by Iressa in these cells (49). Activation of Akt/protein kinase B (PKB) is discussed to predict a worse outcome in patients with ER-positive breast cancer receiving antiestrogens and contributes to an aggressive phenotype of antiestrogen-resistant ER-positive breast cancers (49, 50). Kraus et al. (51) described inhibition of the phosphoinositide 3-kinase Akt/PKB pathway by GnRH analogs in human prostate cancer cells and these effects were amplified by specific phosphoinositide 3-kinase/PKB inhibitors. Further investigations on the effects of GnRH-I and GnRH-II on dimerization of members of the c-erbB family and interference with downstream activation of the ERK and Akt pathway in parental MCF-7 and T47D cells and the resistance-developed sublines are in progress. 
In conclusion, the present study demonstrates antiproliferative effects of GnRH-I and GnRH-II analogs in human breast cancer cells with expression of GnRH-I-R and expression of putative GnRH-II-R. In these cells, analogs of GnRH-I and GnRH-II abrogated effects of EGF-stimulated ERK1/2 activation. The interference of GnRH-I and GnRH-II analogs with the ERK1/2 pathway was accompanied by restored sensitivity to $4 \mathrm{OH}$-tamoxifen in sublines with developed resistance, which showed increased expression of the HER-2 gene product $\mathrm{p} 185$. These results might provide new therapeutic options in the combination treatment of breast cancer with secondary resistance to antiestrogens.

\section{Acknowledgements}

We thank Dr Robert P Millar, Medical Research Council, Human Reproductive Sciences Unit, Edinburgh, Scotland, for the gift of the oligonucleotide primers for the human GnRH-II-R. We thank Ferring-Pharmaceuticals (Copenhagen, Denmark) for supplying the GnRH I-agonist Triptorelin and AstraZeneca (Frankfurt, Germany) for supplying Iressa (gefitinib/ZD1839). We thank Renate Dietrich, Hildtrud Schulz, Kirsten Neßelhut and Mathias Läsche for excellent help and assistance. This study was supported by the GermanIsraeli Foundation for Scientific Research and Development (grant no. I-684-176.2/2000 to G E) and by the Deutsche Forschungsgemeinschaft (grant nos. GR $1895 / 2-1$ and GR $1895 / 2-3$ to $C$ G).

\section{References}

1 Fekete M, Wittliff JL \& Schally AV. Characteristics and distribution of receptors for $\left[\mathrm{D}-\mathrm{TRP}^{6}\right]$-luteinizing hormone-releasing hormone, somatostatin, epidermal growth factor, and sex steroids in 500 biopsy samples of human breast cancer. Journal of Clinical Laboratory Analysis 19893 137-147.

2 Baumann KH, Kiesel L, Kaufmann M, Bastert G \& Runnebaum B. Characterization of binding sites for a GnRH-agonist (buserelin) in human breast cancer biopsies and their distribution in relation to tumor parameters. Breast Cancer Research and Treatment 199325 $37-46$.

3 Moriya T, Suzuki T, Pilichowska M, Ariga N, Kimura N, Ouchi N, Nagura H \& Sasano H. Immunohistochemical expression of gonadotropin releasing hormone receptor in human breast carcinoma. Pathology International $200151333-337$.

4 Mangia A, Tommasi S, Reshkin SJ, Simone G, Stea B, Schittulli F \& Paradiso A. Gonadotropin releasing hormone receptor expression in primary breast cancer: comparison of immunohistochemical, radioligand and Western blot analyses. Oncology Reports 20026 1127-1132.

5 Miller WR, Scott WN, Morris R, Fraser HM \& Sharpe RM. Growth of human breast cancer cells inhibited by a luteinizing hormonereleasing hormone agonist. Nature 1985313 231-233.

6 Blankenstein MA, Henkelmann MS \& Klijn JG. Direct inhibitory effect of a luteinizing hormone-releasing hormone agonist on MCF-7 human breast cancer cells. European Journal of Cancer and Clinical Oncology 198521 1493-1499.

7 Foekens JA, Henkelmann MS, Fukkink JF, Blankenstein MA \& Klijn JG. Combined effects of buserilin, estradiol and tamoxifen on the growth of MCF-7 human breast cancer cells in vitro. Biochemical and Biophysical Research Communications 1986140 $550-556$.

8 Eidne KA, Flanagan CA, Harris NS \& Millar RP. Gonadotropin releasing hormone (GnRH)-binding sites in human breast cancer cell lines and inhibitory effects of GnRH-agonists. Journal of Clinical Endocrinology and Metabolism 198764 425-432.

9 Neri C, Berthois Y, Schatz B, Drieu K \& Martin PM. Compared effects of GnRH analogs and 4-hydroxytamoxifen on growth and steroid receptors in antiestrogen sensitive and resistant MCF-7 breast cancer sublines. Breast Cancer Research and Treatment $19901585-93$.

10 Scott WN, Mullen P \& Miller WR. Factors influencing the response of MCF-7 cells to an agonist of luteinising hormonereleasing hormone. European Journal of Cancer 199127 $1458-1461$.

11 Hershkovitz E, Marbach M, Bosin E, Levy J, Roberts CT Jr, LeRoith D, Schally AV \& Sharoni Y. Luteinizing hormone-releasing hormone antagonists interfere with autocrine and paracrine growth stimulation of MCF-7 mammary cancer cells by insulinlike growth factors. Journal of Clinical Endocrinology and Metabolism 199377 963-968.

12 Szepeshazy K, Milovanovic S, Lapis K, Groot K \& Schally AV. Growth inhibition of estrogen independent MXT mouse mammary carcinomas in mice treated with an agonist or antagonist of LH-RH, an analog of somatostatin, or a combination. Breast Cancer Research and Treatment 199221 181-192.

13 Chen A, Kaganovsky E, Rahimipour S, Ben-Aroya N, Okon E \& Koch Y. Two forms of gonadotropin-releasing hormone $(\mathrm{GnRH})$ are expressed in human breast tissue and overexpressed in breast cancer: a putative mechanism for the antiproliferative effect of GnRH by down-regulation of acidic ribosomal phosphoproteins P1 and P2. Cancer Research 200262 1036-1044.

14 Gründker C, Völker P, Schulz KD \& Emons G. Luteinizing hormone-releasing hormone agonist triptorelin and antagonist cetrorelix inhibit EGF-induced c-fos expression in human gynecological cancers. Gynecologic Oncology 200078 194-202.

15 Emons G, Müller V, Ortmann O, Grossmann G, Trautner U, v Stuckrad B, Schulz KD \& Schally AV. Luteinizing hormonereleasing hormone agonist triptorelin antagonizes signal transduction and mitogenic activity of epidermal growth factor in human ovarian and endometrial cancer cell lines. International Journal of Oncology 19969 1129-1137.

16 Gründker C, Völker P \& Emons G. Antiproliferative signaling of luteinizing hormone-releasing hormone in human endometrial and ovarian cancer cells through $\mathrm{G}$ protein $\alpha_{\mathrm{I}}$-mediated activation of phosphotyrosine phosphatase. Endocrinology 2001 142 2369-2380.

17 Gründker C, Günthert AR, Westphalen S \& Emons G. Biology of GnRH systems in human gynecological cancers. European Journal of Endocrinology 2002146 1-14.

18 Gründker C, Günthert AR, Hellriegel M \& Emons G. Gonadotropinreleasing hormone $(\mathrm{GnRH})$ agonist triptorelin inhibits estradiolinduced serum response element (SRE) activation and c-fos expression in human endometrial, ovarian and breast cancer cells. European Journal of Endocrinology 2004151 619-628.

19 Gründker C, Schulz K, Günthert AR \& Emons G. Luteinizing hormone-releasing hormone induces nuclear factor $\kappa \mathrm{B}$-activation and inhibits apoptosis in ovarian cancer cells. Journal of Clinical Endocrinology and Metabolism 200010 3815-3820.

20 Günthert AR, Gründker C, Hollmann K \& Emons G. Luteinizing hormone-releasing hormone induces JunD-DNA binding and extends cell cycle in human ovarian cancer cells. Biochemical and Biophysical Research Communications 2002294 11-15.

21 King JA \& Millar RP. Coordinated evolution of GnRHs and their receptors. In GnRH Neurones: Gene to Behavior, pp 51-77. Eds PS Parhar \& Y Sakuma. Tokyo: Brain Shuppan Publishers, 1997.

22 Sherwood NM, Lovejoy DA \& Coe IR. Origin of mammalian gonadotropin-releasing hormones. Endocrine Reviews $199314241-254$. 
23 Sealfon SC, Weinstein H \& Millar RP. Molecular mechanisms of ligand interaction with the gonadotropin-releasing hormone receptor. Endocrine Reviews 199718 180-205.

24 Gründker C, Günthert AR, Millar RP \& Emons G. Expression of gonadotropin-releasing hormone II (GnRH-II) receptor in human endometrial and ovarian cancer cells and effects of GnRH-II on tumor cell proliferation. Journal of Clinical Endocrinology and Metabolism 200287 1427-1430.

25 Gründker C, Schlotawa L, Viereck V, Eicke N, Horst A, Kairies B \& Emons G. The antiproliferative effects of GnRH antagonist Cetrorelix and of GnRH-II on human endometrial and ovarian cancer cells are not mediated through the GnRH type I (GnRH-I) receptor. European Journal of Endocrinology 2004152 141-149.

26 Kurokawa H, Lenferink AE, Simpson JF, Pisacane PI, Sliwkowski MX, Forbes JT \& Arteaga CL. Inhibition of HER2/neu (erbB-2) and mitogen-activated protein kinases enhances tamoxifen action against HER2-overexpressing, tamoxifen-resistant breast cancer cells. Cancer Research 200060 5887-5894.

27 Knowlden JM, Hutcheson IR, Jones HE, Madden T, Gee JM, Harper ME, Barrow D, Wakeling AE \& Nicholson RI. Elevated levels of epidermal growth factor receptor/c-erbB2 heterodimers mediate an autocrine growth regulatory pathway in tamoxifenresistant MCF-7 cells. Endocrinology 2003 144 1032-1044.

28 Wakeling AE, Guy SP, Woodburn JR, Ashton SE, Curry BJ, Baker AJ \& Gibson KH. ZD1839 (Iressa): an orally active inhibitor of epidermal growth factor signaling with potential for cancer therapy. Cancer Research 200262 5749-5753.

29 Völker P, Gründker C, Schmidt O, Schulz KD \& Emons G. Expression of receptors for luteinizing hormone-releasing hormone in human ovarian and endometrial cancers: frequency, autoregulation, and correlation with direct antiproliferative activity of luteinizing hormone-releasing hormone analogues. American Journal of Obstetrics and Gynecology $2002 \mathbf{1 8 6}$ $171-179$.

30 Emons G, Ortmann O, Becker M, Irmer G, Springer B, Laun R, Hölzel F, Schulz KD \& Schally AV. High affinity binding and direct antiproliferative effects of LHRH analogues in human ovarian cancer cell lines. Cancer Research 199353 5439-5446.

31 Nicoletti I, Migloriati G, Pagliacci MC, Grignani F \& Ricardi C. A rapid and simple method for measuring thymocyte apoptosis by propidium iodide staining and flow cytometry. Journal of Immunological Methods 1991139 271-279.

32 Neill JD, Duck LW, Sellers JC \& Musgrove LC. A gonadotropinreleasing hormone $(\mathrm{GnRH})$ receptor specific for $\mathrm{GnRH}$ II in primates. Biochemical and Biophysical Research Communications $20012821012-1018$.

33 Millar RP, Conklin D, Lofton-Day C, Hutchinson E, Troskie B, Illing N, Sealfon SC \& Hapgood J. A novel human GnRH receptor homolog gene: abundant and wide tissue distribution of the antisense transcript. Journal of Endocrinology $1999 \mathbf{1 6 2} 117-126$.

34 Neill JD. GnRH and GnRH receptor genes in the human genome. Endocrinology $2002 \mathbf{1 4 3} 737-743$.

35 Millar RP. GnRH II and type II GnRH receptors. Trends in Endocrinology and Metabolism 200314 35-43.

36 Millar R, Lowe S, Conklin D, Pawson A, Maudsley S, Troskie B, Ott T, Millar M, Lincoln G, Sellar R, Faurholm B, Scobie G, Kuestner R, Terasawa E \& Katz A. A novel mammalian receptor for the evolutionarily conserved type II GnRH. PNAS $20019 \mathbf{9 8}$ 9636-9641.

37 Morgan K, Conklin D, Pawson AJ, Sellar R, Ott TR \& Millar RP. A transcriptionally active human type II gonadotropin-releasing hormone receptor gene homolog overlaps two genes in the antisense orientation on chromosome 1q.12. Endocrinology 2003 $144423-436$.
38 van Biljon W, Wykes S, Scherer S, Krawetz S \& Hapgood J. Type II gonadotropin-releasing hormone transcripts in human sperm. Biology of Reproduction $2002671741-1749$.

39 Enomoto M, Endo D, Kawashima S \& Park MK. Human type II GnRH receptor mediates effects of $\mathrm{GnRH}$ on cell proliferation. Zoological Science 2004 21 763-770.

40 Eicke N, Günthert AR, Viereck V, Siebold D, Béhé M, Becker T, Emons G, \& Gründker C. GnRH-II receptor-like antigenicity in human placenta and in cancers of human reproductive organs. European Journal of Endocrinology 2005 (in press).

41 Kim KY, Choi KC, Park SH, Auersperg N \& Leung PC. Extracellular signal-regulated protein kinase, but not c-jun $\mathrm{N}$-terminal kinase, is activated by type II gonadotropin-releasing hormone involved in the inhibition of ovarian cancer cell proliferation. Journal of Clinical Endocrinology and Metabolism 200590 $1670-1677$.

42 Kato S, Endoh E, Masuhiro Y, Kitamoto T, Uchiyama S, Sasaki H, Masushige S, Gotoh Y, Nishida E, Kawashima H, Metzger D \& Chambon P. Activation of the estrogen receptor through phosphorylation by mitogen-activated protein kinase. Science 1995 $2701491-1494$.

43 Bunone G, Briand PA, Miksicek RJ \& Picard D. Activation of the unliganded estrogen receptor by EGF involves the MAP kinase pathway and direct phosphorylation. EMBO Journal 199615 2174-2183.

44 Jackson TA, Richer JK, Bain DL, Takimoto GS, Tung L \& Horwitz KB. The partial agonist activity of antagonist-occupied steroids receptors is controlled by a novel hinge domain-binding coactivator L7/SPA and the corepressors N-CoR or SMRT. Molecular Endocrinology 199711 693-705.

45 Riese DJ 2nd \& Stern DF. Specificity within the EGF family/ErbB receptor family signaling network. Bioassays 199820 41-48.

46 Nicholson RI, McClelland RA, Finlay P, Eaton CL, Gullick WJ, Dixon AR, Robertson JF, Ellis IO \& Blamey RW. Relationship between EGF-R, c-erbB-2 protein expression and Ki67 immunostaining in breast cancer and hormone sensitivity. European Journal of Cancer $1993291018-1023$.

47 van Agthoven T, van Agthoven TL, Portengen H, Foekens JA \& Dorssers LC. Ectopic expression of epidermal growth factor receptors induces hormone independence in ZR-75-71 human breast cancer cells. Cancer Research 199252 5082-5088.

48 Gee JM, Harper ME, Hutcheson IR, Madden TA, Barrow D, Knowlden JM, McClelland RA, Jordan N, Wakeling AE \& Nicholson RI. The antiepidermal growth factor receptor agent gefitinib (ZD1839/Iressa) improves antihormone response and prevents development of resistance in breast cancers in vitro. Endocrinology $2003 \mathbf{1 4 4} 5105-5117$.

49 Jordan JN, Gee JMW, Barrow D, Wakeling AE \& Nicholson RI. Increased constitutive activity of $\mathrm{PKB} /$ Akt in tamoxifen resistant breast cancer MCF-7 cells. Breast Cancer Research and Treatment 200487 167-180.

50 Perez-Tenorio G \& Stal O. Activation of AKT/PKB in breast cancer predicts a worse outcome among endocrine treated patients. British Journal of Cancer $2002 \mathbf{8 6} 540-545$.

51 Kraus S, Levy G, Hanoch T, Naor Z \& Seger R. Gonadotropinreleasing hormone induces apoptosis of prostate cancer cells: role of c-Jun NH2-terminal kinase, protein kinase B, and extracellular signal-regulated kinase pathways. Cancer Research 2004 $645736-5744$.

Received 2 June 2005

Accepted 6 July 2005 